\title{
Edaphic Macrofauna as a Recovery Indicator of Abandoned Areas of Corymbia citriodora in the Southeastern Brazil
}

\author{
Paola Maia Lo Sardo ${ }^{1}$ (D), Juliano Silva Lima ${ }^{1,2}$
}

${ }^{1}$ Universidade Estadual do Norte Fluminense Darcy Ribeiro - UENF, Campos dos Goytacazes/RJ, Brasil ${ }^{2}$ Instituto Federal de Sergipe - IFS, Nossa Senhora da Glória/SE, Brasil

\begin{abstract}
The edaphic macrofauna may reflect changes in soil use. This study aimed to answer two questions: (1) Has the management of eucalyptus by girdling, promote stimulation or inhibition in the guilds of the edaphic macrofauna? (2) Can soil macrofauna be used as an indicator of the recovery of abandoned eucalyptus areas? For that purpose, we compared the composition and diversity of the edaphic macrofauna in areas of secondary forest, abandoned non-girdled eucalyptus plantations and girdled eucalyptus plantations. The secondary forest presented greater richness, abundance and diversity of edaphic macrofauna, followed by areas of girdled eucalyptus, with the lowest values found in areas with non-girdled eucalyptus. Therefore, the edaphic macrofauna responded to the management by girdling, through the stimulation of the taxonomic groups in the different guilds and can be indicated as a good indicator of the recovery of disturbed areas.
\end{abstract}

Keywords: fauna of the soil, guilds, abandoned plantations, eucalyptus, management. 


\section{INTRODUCTION}

The decomposition of organic matter in the soil is an essential biological process for the ecosystem, being the main path of carbon and nitrogen cycling (Handa et al., 2014; Crotty et al., 2014; Laird-Hopkins et al., 2017; Yin et al., 2019). The mineralization and immobilization of nutrients are carried out by a variety of structured organisms in a complex trophic network: decomposers microorganisms; invertebrates of the soil that act as consumers, and the plants, which produce the litterfall (Coyle et al., 2017; Tacca et al., 2017).

The edaphic fauna establishment, especially the macrofauna, is due to the quality and quantity of the deciduous material, mainly in tropical environments (Handa et al., 2014; Borges et al., 2019). The interaction of the edaphic macrofauna with the decomposers microorganisms and the plants is able to modify functional and structurally the soil, exerting a regulation on the nutrients decomposition and cycling processes (Marx et al., 2016; Coyle et al., 2017; Laird-Hopkins et al., 2017; Wu \& Wang, 2019).

The morphological, physiological and behavioral characteristics of the edaphic macrofauna determine the type of feeding and movement of these organisms. The shape (soil ingestion, use of the jaws, drilling or excavation) and the direction (horizontal and vertical) of this organisms' displacement promote the fragmentation and distribution of organic matter and nutrients and the aeration and infiltration of water in the soil (Melo et al., 2009; Baretta et al., 2011; Correia et al., 2018).

Studies in terrestrial and aquatic environments from the subarctic to the tropics have shown that the loss of decomposing organisms' functional diversity from the soil macrofauna and litterfall types of plants has reduced the decomposition of litterfall and, consequently, the cycling of most of the elements (Silva et al., 2012; Laird-Hopkins et al., 2017; Amazonas et al., 2018; Ferreira et al., 2018).

Changes in land use and forest fragmentation have been one of the changing factors in the structure and composition of the soil macrofauna community (Baretta et al., 2011; Maestri et al., 2013; Camara et al., 2018; Silva et al., 2018; Nunes et al., 2019). Studies have verified that this effect also occurs when native forests are replaced by monocultures, even though forest (Suguituru et al., 2011; Camara et al., 2012; Silva et al., 2012; Marques et al., 2014; Tacca et al., 2017; Rodrigues et al., 2017; Kooch et al., 2018).

This capacity of the soil macrofauna to reflect changes occurring in soil and litterfall due to the fragmentation of the environments and the changes in soil use allow the pedofauna to be an efficient ecological indicator to access the recovery of areas after disturbances (Zardo et al., 2010; Silva et al., 2013; Nakamura et al., 2011; Vasconcellos et al., 2013; Majeed et al., 2018).

Studies in temperate (Castro \& Wise, 2009; Ober $\&$ Degroote, 2011) and tropical forests (Sayer et al., 2010; Suguituru et al., 2011; Camara et al., 2012; Maestri et al., 2013; Marques et al., 2014) investigated the response of edaphic fauna compared to the substitution of native forests for silviculture. However, there is still little research in tropical environments investigating the influence of edaphic macrofauna on abandoned silviculture areas at different levels of natural regeneration.

Therefore, this study investigates whether the composition and diversity of soil macrofauna reflects the recovery of abandoned silviculture areas, especially in abandoned eucalyptus plantations of the species (Corymbia citriodora (Hook.) K.D. Hill \& L.A.S. Johnson). And to understand whether the management of eucalyptus by girdling can alter the composition of the soil macrofauna guilds.

The present study aimed to compare the composition and diversity of soil macrofauna in three phytophysiognomies (secondary forests, girdled eucalyptus areas and abandoned eucalyptus areas) and to evaluate the soil macrofauna as an indicator of recovery of eucalyptus areas (C. citriodora) abandoned in the Biological Reserve União, Rio de Janeiro.

The hypothesis tested was that eucalyptus areas that have been managed by girdling present greater richness, abundance and diversity of the edaphic macrofauna when compared to the unmanaged eucalyptus areas. And that the management by girdling promotes the stimulation of the edaphic macrofauna guilds, in view of the diversification and improvement of the litterfall quality, the greater availability of woody material for decomposition, the reduction of the eucalyptus allelopathic action and the advance of natural regeneration. 


\section{MATERIAL AND METHODS}

\subsection{Study area}

For the accomplishment of the present study, three phytophysiognomies were selected in the Biological Reserve União (Rebio União, Figure 1), two areas of secondary forest [SF1 (S22 $\left.25^{\prime} 14.9^{\prime \prime}, \mathrm{W} 42^{\circ} 01^{\prime} 56.1^{\prime \prime}\right)$ and SF2 (S22 $\left.\left.25^{\prime} 19.3^{\prime \prime}, \mathrm{W} 42^{\circ} 02^{\prime} 27.5^{\prime \prime}\right)\right]$, used as reference areas, two areas with abandoned non-girdled eucalyptus plantation [NE1 (S22 26 $\left.02.6^{\prime \prime}, \mathrm{W}^{\circ} 2^{\circ} 02^{\prime} 34.4^{\prime \prime}\right)$ and NE2 (S22 $\left.\left.25^{\prime} 28.2^{\prime \prime}, \mathrm{W} 42^{\circ} 02^{\prime} 24.6^{\prime \prime}\right)\right]$ and two areas with abandoned eucalyptus plantation, where the trees were managed by girdling for their elimination [GE1 (S22 $\left.{ }^{\circ} 25^{\prime} 44.9^{\prime \prime}, \mathrm{W} 42^{\circ} 02^{\prime} 15.3^{\prime \prime}\right)$ and GE2 (S22 $25^{\prime} 35.0^{\prime \prime}$, $\left.\left.\mathrm{W} 42^{\circ} 02^{\prime} 27.5^{\prime \prime}\right)\right]$, and the managements were carried out respectively in 2016 and in 2013.

In 1998, the Rebio União was created, with approximately 2,548 ha, forming a mosaic of different uses of the soil (native vegetation, abandoned eucalyptus plantations, fields and pastures) (ICMBio, 2007).
This reserve extends by the municipalities of Rio das Ostras, Casimiro de Abreu and Macaé, in the state of Rio de Janeiro. In the Rebio União there are a total of 47 abandoned eucalyptus plantations (plots), with different ages (1960-1993), which comprises an area between 0.21 and 16.36 ha. Since 2008, areas with abandoned eucalyptus plantation are being managed by cutting back or girdling the trees to eliminate the crop, in order to facilitate the process of natural regeneration (ICMBio, 2008).

\subsection{Data collect}

The collection of the soil macrofauna was performed using fall traps, pitfalls type (Baretta et al., 2011). In the six areas studied, five pitfalls traps were installed with a spacing of five meters between them along a transect $30 \mathrm{~m}$ from the edge of each area. The traps consisted of plastic pots $(450 \mathrm{~mL})$ filled with $250 \mathrm{~mL}$ of water with detergent and were installed in a cavity, with the opening at the soil level. Two collections were carried
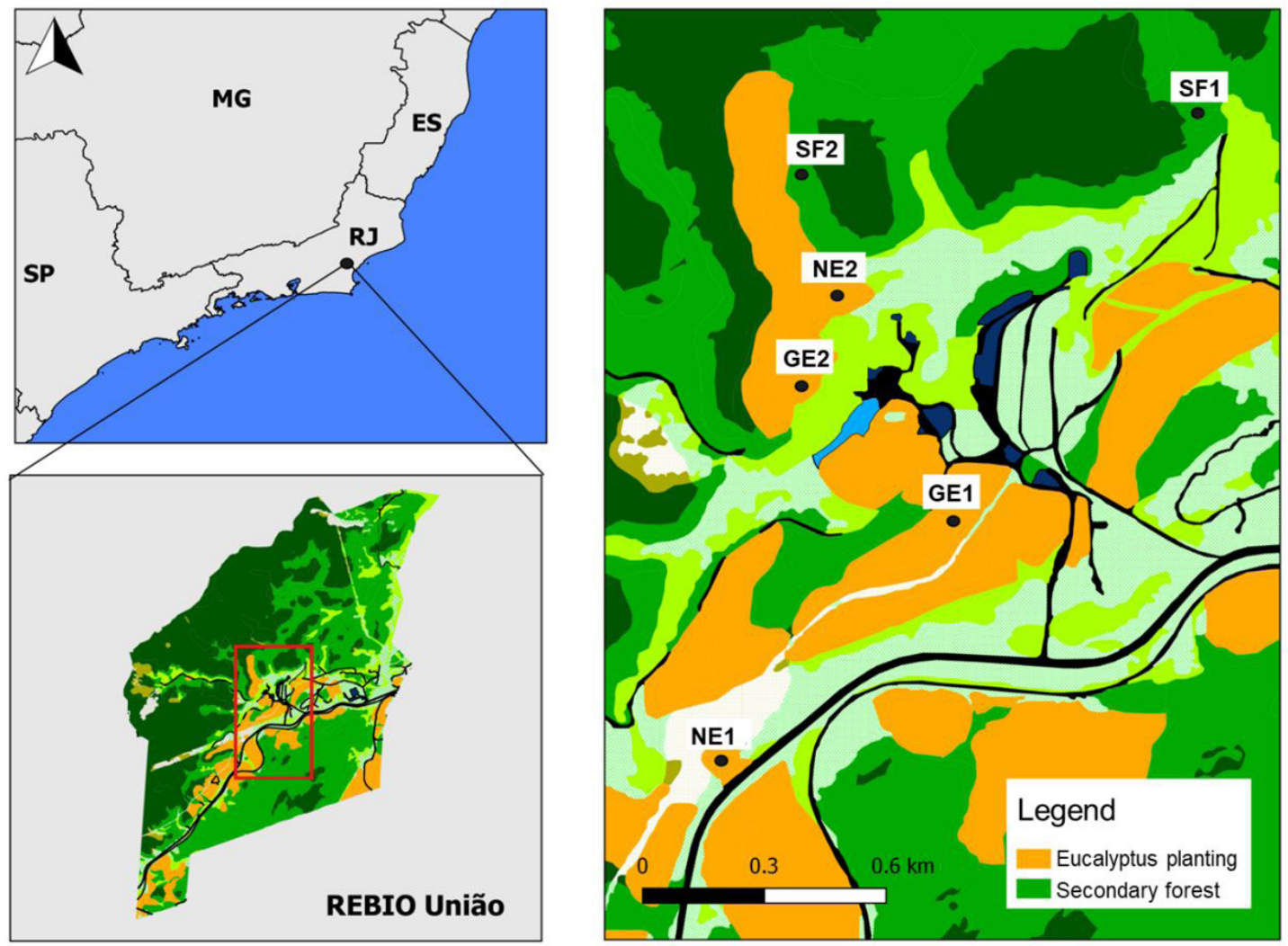

Figure 1. Location of the six study areas in the Biological Reserve União, state of Rio de Janeiro, Brazil. Phytophysiognomies: SF = Secondary forest; GE = Girdled Eucalypt; and NE = Non-girdled Eucalyptus. 
out for 48 hours, and the captured individuals were collected every 24 hours and the content of the trap reset. The individuals were screened and stored in $70 \%$ alcohol solution. The individuals were identified in taxonomic groups (order or family) with the help of binocular loupe and determination taxonomic. The option to identification in large groups was made, since the species is not always the best ecological unit to evaluate the functionality of organisms in the environments (Gerisch et al., 2012).

We collected environmental predictors (litterfall height and weight, temperature, humidity) to relate to the values of the community descriptors (number of individuals $(\mathrm{N})$, richness (S), Shannon-Wiever index $\left(H^{\prime}\right)$. In each transect five points were delimited every $2.5 \mathrm{~m}$ of the pitfall trap. At each point, the height of the litterfall was measured and the litterfall was collected within one quadrant $\left(0.25 \mathrm{~m}^{2}\right)$. The litterfall was stored and the samples weighed (fresh weight). We collected mean temperature and mean humidity using a digital thermohygrometer in each area for 24 hours.

\subsection{Data analysis}

The spatial variation of the macrofauna descriptors (number of individuals, richness, Shannon-Wiever index) was determined by the Permutational Analysis of Variance (PERMANOVA) based on the similarity of Bray Curtis. We compared the number of individuals, richness and diversity among the following fixed factors: phytophysiognomies (Secondary Forest, Girdled Eucalyptus, Non-girdled Eucalyptus) and collection areas (SF1, SF2, GE1, GE2, NE1, NE2). The PERMANOVA test (pair-wise test) was performed to compare the phytophysiognomies. The $p$ used for the analysis of phytophysiognomy communities was the $\mathrm{p}$ (Monte Carlos) due to the low number of permutations performed by PERMANOVA's analysis. The significance level adopted for all analyzes was 0.05 .

Multivariate analyzes were performed: non-metric multidimensional scaling (nMDS) to evaluate the association pattern of the edaphic macrofauna taxa among the studied areas. The percentage similarity procedure (SIMPER) defined the percentage contribution of each taxonomic group among the phytophysiognomies. The values of the logarithmized community from the descriptors $[\log (x+1)]$ and the Bray Curtis coefficient of similarity were used for the multivariate analysis. The multiple linear regression analysis was used to determine the influence of potential environmental predictors on univariate descriptors of the macrofauna community, the analyzes were generated through $\mathrm{R}$ program.

The Change Index (Wardle \& Parkinson, 1991) was used to evaluate the effects on the abundance of edaphic macrofauna from the management by girdling in eucalyptus. This index indicates disturbances or stability in the richness and abundance of the edaphic macrofauna as a response to a certain management applied to the area (Cunha et al., 2012). For the analysis of this index, the individuals collected were classified into six distinct guilds, based on the position in the soil trophic chain and on the life strategies: Saprophagous - Decomposers organisms (Blattodea, Diplopoda and Isopoda); Predators - Organisms feed on the soil fauna (Araneae, Neuroptera, Pseudoscorpiones and Opiliones); Herbivores - Organisms feed on vegetables (Lepidoptera larvae, Orthoptera and Stylommatophora); Phytophagous - Organisms feed on sap (Hemiptra and Thysanoptera); Ecosystem engineers - Organisms that create or maintain habitats for other species (Formicidae, Isoptera and Haplotaxida) and Diverse strategies - Organisms that have diversified strategies (Coleoptera, Diptera and Vespidae) (Swift et al., 2010).

The change index is calculated by the Formula 1 :

$V=((2 x / x+y)-1)$

where $\mathrm{x}=$ abundance of the taxonomic group in the girdled eucalyptus area; and $y=$ abundance of the taxonomic group in the non-girdled eucalyptus area.

According to this index, the soil macrofauna was included in categories (modified from Wardle \& Parkinson, 1991; Cunha et al. 2012), as presented in Table 1.

Table 1. Inhibition and stimulation categories of the soil fauna groups in response to the intervention process, based on the $\mathrm{V}$ index.

\begin{tabular}{lcr}
\multicolumn{1}{c}{ Category } & Symbol & \multicolumn{1}{c}{ V Index } \\
Extreme Inhibition & EI & V $<-0.67$ \\
Moderate inhibition & MI & $-0.33>\mathrm{V}<-0.67$ \\
\hline Light inhibition & LI & $-0.05>\mathrm{V}<-0.33$ \\
Without changes & WC & $-0.05>\mathrm{V}<0.05$ \\
Light Stimulation & LS & $0.05>\mathrm{V}<0.33$ \\
Moderate stimulation & MS & $0.33>\mathrm{V}<0.67$ \\
Extreme stimulation & ES & $\mathrm{V}>0.67$ \\
\hline $\begin{array}{l}\text { Source: Modified from } \\
\text { Cunha et al. (2012). }\end{array}$ & &
\end{tabular}




\section{RESULTS}

\subsection{Characterization and comparison of edaphic communities}

Throughout the study, we sampled a total of 876 individuals belonging to 18 taxonomic groups. The most abundant groups were Formicidae ( $\mathrm{N}=248$ individuals), Isopoda $(\mathrm{N}=116)$ and Coleoptera $(\mathrm{N}=111)$. We also collected individuals from the Isoptera $(\mathrm{N}=77)$, Diptera ( $\mathrm{N}=63)$, Vespidae $(\mathrm{N}=48)$, Araneae $(\mathrm{N}=37)$, Orthoptera $(\mathrm{N}=33)$, Hemiptera $(\mathrm{N}=32)$, Blattodea $(\mathrm{N}=26)$, Thysanoptera $(\mathrm{N}=22)$, Haplotaxida $(\mathrm{N}=16)$, Diplopode $(\mathrm{N}=15)$, Lepidoptera Larvae, $(\mathrm{N}=11)$, Pseuduscorpionida $(\mathrm{N}=10)$, Neuroptera $(\mathrm{N}=7)$, Stylommatophora $(\mathrm{N}=6)$ and Opiliones $(\mathrm{N}=2)$.

Soil macrofauna community descriptors differed in the three phytophysiognomies secondary forest, girdled eucalypt and non-girdled eucalyptus. The total number of individuals was higher in the second forest $(\mathrm{N}=358)$, followed by girdled eucalyptus $(\mathrm{N}=310)$ and non-girdled eucalyptus $(\mathrm{N}=213)$. The values of abundance, richness and diversity $\left(\mathrm{H}^{\prime}\right)$ followed the same pattern for the evaluated vegetation types (Figure 2).

An analysis of the boxplots, based on the edaphic macrofauna for the phytophysiognomy and areas, shows difference in the community structure among the vegetation $(\mathrm{SF}>\mathrm{GE}>\mathrm{NE}$ ) and shows greater similarity among the areas with the same phytophysiognomy. The structure of the edaphic macrofauna community differed significantly $[\mathrm{p}(\mathrm{MC})=0.003]$ among the different phytophysiognomies. The vegetation of secondary forest and non-girdled eucalyptus had a significant difference $[\mathrm{p}(\mathrm{MC})=0.005]$ (Table 2).

The nMDS ordering analysis revealed the formation of three major groups based on the association pattern of the edaphic macrofauna (Figure 3). The first arrangement ( $66.31 \%$ of similarity) is formed by the soil macrofauna
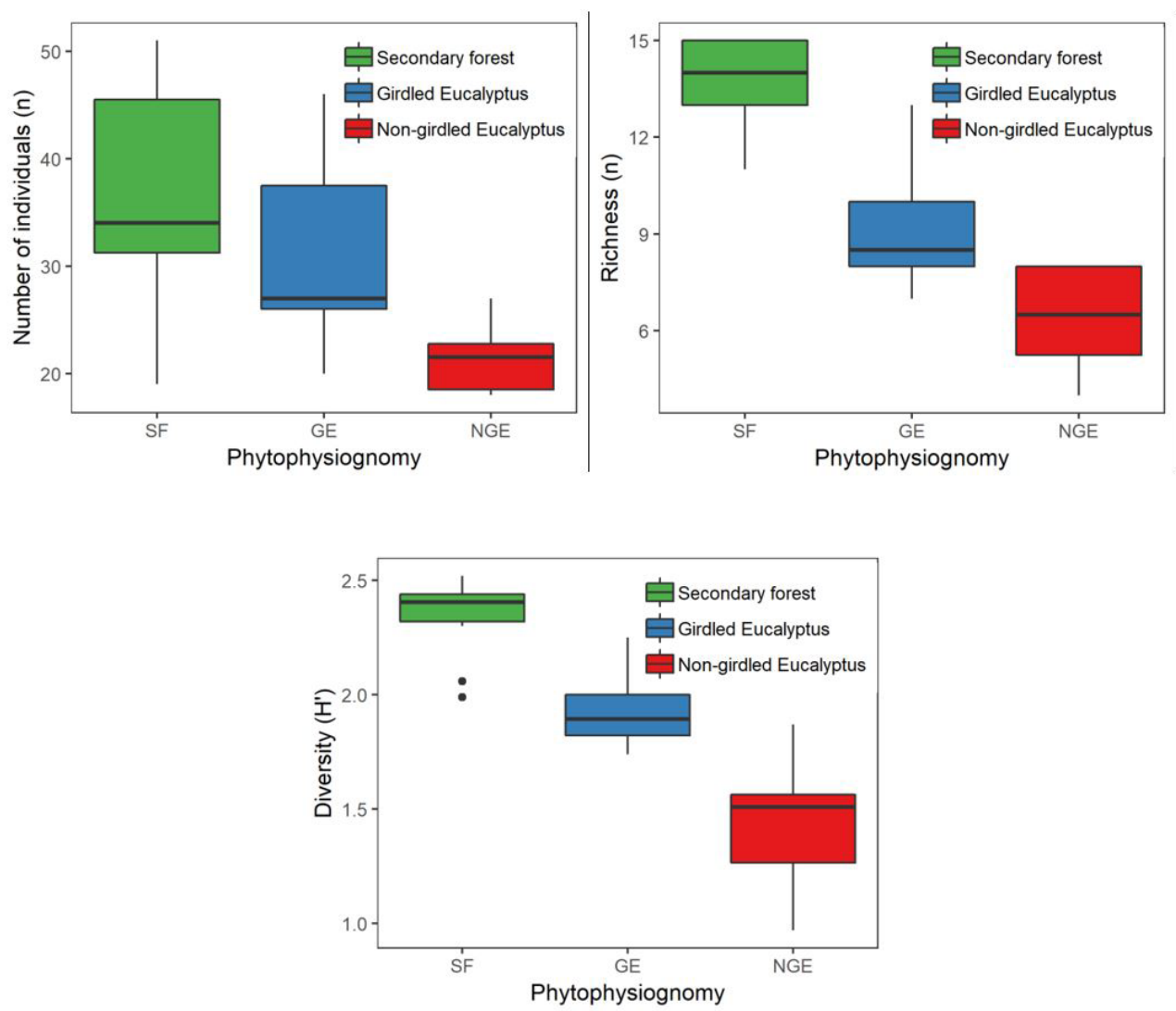

Figure 2. Boxplots of the abundance, richness and diversity $\left(\mathrm{H}^{\prime}\right)$ of edaphic macrofauna in the three phytophysiognomies. The black line and the boxes represent the median values and interquartile range, respectively; the line bars are standard deviation and the points are outliers. 
Table 2. Results of the PERMANOVA analysis and the Pair-Wise test among the areas of different phytophysiognomies (Secondary Forest, Girdled Eucalyptus, Non-Girdled Eucalyptus) and collection areas (SF1, SF2, GE1, GE2, NE1, NE2) as to the community structure of the edaphic macrofauna.

\begin{tabular}{|c|c|c|c|c|c|c|c|}
\hline Source & Df & SS & MF & Pseudo-F & $p$ (perm) & Perms & $p(\mathrm{MC})$ \\
\hline Phytophysiognomy & 2 & 7267.2 & 3633.6 & 60.8 & 0.065 & 15 & $0.003^{\star *}$ \\
\hline Areas & 3 & 1792.3 & 597.44 & 14.5 & 0.126 & 997 & 0.132 \\
\hline Residues & 24 & 9832.5 & 409.69 & & & & \\
\hline Total & 29 & 18892 & & & & & \\
\hline \multicolumn{8}{|c|}{ Pair-Wise Test } \\
\hline \multicolumn{4}{|c|}{ Phytophysiognomy } & $\mathbf{T}$ & $p($ perm $)$ & Perms & $p(\mathrm{MC})$ \\
\hline \multicolumn{4}{|c|}{ Secondary forest, Girdled Eucalyptus } & 23.954 & 0.341 & 3 & $0.009^{* *}$ \\
\hline \multicolumn{4}{|c|}{ Secondary forest, Eucalyptus not girdled } & 29.315 & 0.343 & 3 & $0.005^{\star *}$ \\
\hline \multicolumn{4}{|c|}{ Girdled eucalyptus, Non-girdled Eucalyptus } & 20.358 & 0.34 & 3 & $0.037^{\star}$ \\
\hline
\end{tabular}

Df = Degrees of freedom; SS = Sums of squares; MF = Mean squares; Pseudo-F = Pseudo-F ratio; $p($ perm $)=$ Permutation $p$-value; Perms $=$ Number of permutations; $p(\mathrm{MC})=$ Monte Carlo $p$-values; $p(\mathrm{MC})={ }^{*} p<0.05$ and ${ }^{* *} p<0.01$.

from the non-girdled eucalyptus areas and includes five taxonomic groups that contributed with $90.91 \%$ for the total similarity of this group. The taxa that contributed to this group were: Formicidae (41.45\%), Coleoptera (20.29\%), Isopoda (16.14\%), Diptera (8.19\%) and Vespidae (4.48\%).

The second group (69.72\% of similarity) includes the edaphic macrofauna of GE areas and eight taxonomic groups (91.86\%) contributed to total similarity. The taxa that contributed to this group were: Formicidae (23.81\%), Isoptera (19.18\%), Isopoda (17.87\%), Coleoptera (13.98\%), Diptera (6.95\%), Orthoptera (3.81\%), Thysanoptera (3.43\%) and Blattodea (2.84\%). The third group (70.52\% of similarity) included macrofauna mainly of the second forest and 13 taxonomic groups contributed with $92.09 \%$ of the total similarity, being the taxa: Formicidae (14.73\%), Isopoda (12.57\%), Coleoptera (12.34\%), Orthoptera (8.11\%), Araneae (6.39\%), Hemiptra (5.92\%), Diptera (5.53\%), Haplotaxide (5.52\%), Isoptera (5.38\%), Blattodea (5.1\%) and Diplopoda (3.15\%).

The SIMPER also pointed to Orthoptera as the taxonomic group that contributed the most to the dissimilarity between second forest and non-girdled eucalyptus (46.88\%). On the other hand, Isoptera was the taxon that most contributed to dissimilarities between the areas of girdled eucalyptus versus non-girdled eucalyptus (41.06\%) and versus second forest (35.81\%).

\subsection{Environmental predictors}

Humidity was a significant environmental predictor $(\mathrm{p}<0.01)$ for all macrofauna community descriptors evaluated (abundance, richness, and diversity). In all descriptors, moisture was positively associated with the macrofauna (Table 3 ), presenting a high predictive relation with increased abundance $\left(\mathrm{R}^{2}=0.36\right)$, richness $\left(\mathrm{R}^{2}=0.57\right)$ and diversity $\left(\mathrm{R}^{2}=0.63\right)$ of the edaphic macrofauna (Figure 4).

On the other hand, the height and weight of the litterfall were not good environmental predictors to explain the community descriptors in the analyzed areas (Table 3). The temperature was not inserted in the matrix of the multiple regression, considering that in the PCA analysis the humidity and the temperature presented covariance.

\subsection{Change index}

The soil macrofauna was distributed in categories according to the values calculated for the Change Index $(\mathrm{V})$. In the GE areas, no taxonomic group disappeared, 12 taxa were stimulated, and three groups were inhibited when compared to areas where C. citriodora was not submitted to girdling (Table 4). The management of eucalyptus caused changes and increases in the edaphic macrofauna guilds. The most stimulated guild was the saprophagous (three stimulated groups). The predators, herbivores, phytophagous and ecosystem engineers were guilds each with two stimulated groups. The taxonomic groups that were extremely stimulated (ES) were Neuroptera, Orthoptera, Thysanoptera, Haplotaxida (collected only in GE) and Isoptera. However, we observed inhibition of Opiliones, Vespidae and Formicidae groups. The taxonomic groups Pseudoscopiones and Stylommatophora were not registered in the girdled eucalyptus areas, these were restricted to the areas of second forest. 
Table 3. Multiple regression analysis of moisture values related to number of individuals, soil richness and macrofauna diversity.

\begin{tabular}{|c|c|c|c|c|c|c|}
\hline & \multicolumn{2}{|c|}{ Number of individuals } & \multicolumn{2}{|c|}{ Richness } & \multicolumn{2}{|c|}{ Diversity (H') } \\
\hline & $\mathbf{R}^{2}$ & $p$-value & $\mathbf{R}^{2}$ & p-value & $\mathbf{R}^{2}$ & $p$-value \\
\hline Litterfall $(\mathrm{cm})$ & 0.0519 & 0.3414 & 0.039 & 0.9374 & 0.0288 & 0.7116 \\
\hline Litterfall (g) & 0.0097 & 0.0549 & 0.0446 & 0.5723 & 0.042 & 0.4258 \\
\hline Humidity/Moisture & 0.3568 & $0.0048^{\star *}$ & 0.5727 & $5.58 \mathrm{E}-07^{\star *}$ & 0.6361 & $5.64 \mathrm{E}-07^{* *}$ \\
\hline Multiple Regression & 0.4184 & $0.0247^{*}$ & 0.6563 & $3.22 \mathrm{E}-05^{\star *}$ & 0.7069 & $4.21 \mathrm{E}-06^{* *}$ \\
\hline Residue & 0.5816 & - & 0.3437 & - & 0.2931 & - \\
\hline
\end{tabular}

$\mathrm{R}^{2}=$ Coefficient of determination; $p$-value $={ }^{*} p<0.05$ and ${ }^{* *} p<0.01$

Table 4. Categories of the V Index for total abundance of the soil macrofauna distributed in guilds in the areas of non-girdled eucalyptus and girdled eucalyptus in the Biological Reserve União, Rio de Janeiro.

\begin{tabular}{|c|c|c|c|c|c|}
\hline Guilds & Groups & NE (N) & GE (N) & V Index & Category \\
\hline \multirow{5}{*}{ Saprophagous } & Blattodea & 7 & 8 & 0.07 & LS \\
\hline & Diplopoda & 1 & 2 & 0.33 & MS \\
\hline & Isopoda & 28 & 50 & 0.28 & LS \\
\hline & Inhibited groups & & & & 0 \\
\hline & Stimulated groups & & & & 3 \\
\hline \multirow{6}{*}{ Predators } & Araneae & 7 & 8 & 0.07 & LS \\
\hline & Neuroptera & 0 & 1 & 1.00 & ES \\
\hline & Pseudoscorpiones & 0 & 0 & 0.00 & WC \\
\hline & Opilionidae & 2 & 0 & -1.00 & EI \\
\hline & Inhibited groups & & & & 1 \\
\hline & Stimulated groups & & & & 2 \\
\hline \multirow{5}{*}{ Herbivores } & Lepidoptera larvae & 2 & 3 & 0.20 & LS \\
\hline & Orthoptera & 0 & 12 & 1.00 & ES \\
\hline & Stylommatophora & 0 & 0 & 0.00 & WC \\
\hline & Inhibited groups & & & & 0 \\
\hline & Stimulated groups & & & & 2 \\
\hline \multirow{4}{*}{ Phytophagous } & Hemiptera & 5 & 9 & 0.29 & LS \\
\hline & Thysanoptera & 0 & 14 & 1.00 & ES \\
\hline & Inhibited groups & & & & 0 \\
\hline & Stimulated groups & & & & 2 \\
\hline \multirow{5}{*}{ Ecosystem Engineer } & Formicidae & 97 & 82 & -0.08 & LI \\
\hline & Isoptera & 3 & 52 & 0.89 & ES \\
\hline & Haplotaxida & 0 & 4 & 1.00 & ES \\
\hline & Inhibited groups & & & & 1 \\
\hline & Stimulated groups & & & & 2 \\
\hline \multirow{5}{*}{ Several strategies } & Coleoptera & 34 & 33 & -0.01 & WC \\
\hline & Diptera & 13 & 22 & 0.26 & LS \\
\hline & Vespidae & 14 & 9 & -0.22 & LI \\
\hline & Inhibited groups & & & & 1 \\
\hline & Stimulated groups & & & & 1 \\
\hline
\end{tabular}

$\mathrm{NE}(\mathrm{N})=$ Number of individuals of soil macrofauna in non-girdled eucalyptus; $\mathrm{GE}(\mathrm{N})=$ Number of individuals of soil macrofauna in girdled eucalyptus; V index = Change index; EI = Extreme Inhibition; LI = Light Inhibition; WC = Without Change; LS = Light Stimulation; MS = Moderate Stimulation; ES = Extreme Stimulation. 


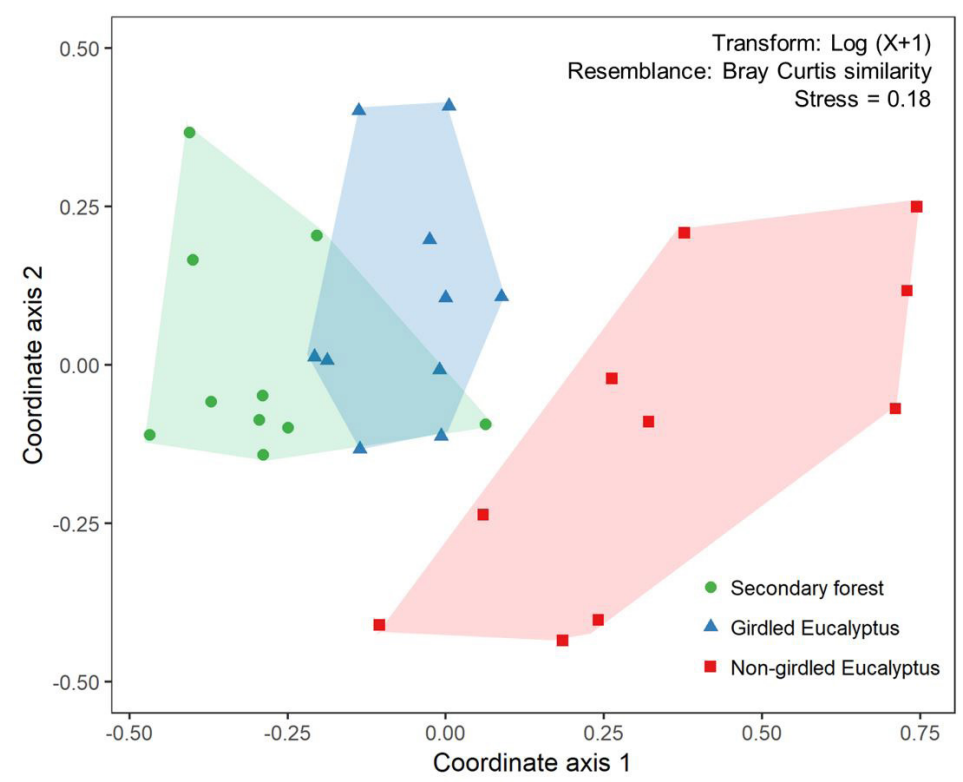

Figure 3. Ordering by the multivariate analysis nMDS based on the community structure of the edaphic macrofauna in the different phytophysiognomies. The polygons drawn from Bray-Curtis similarity cluster.
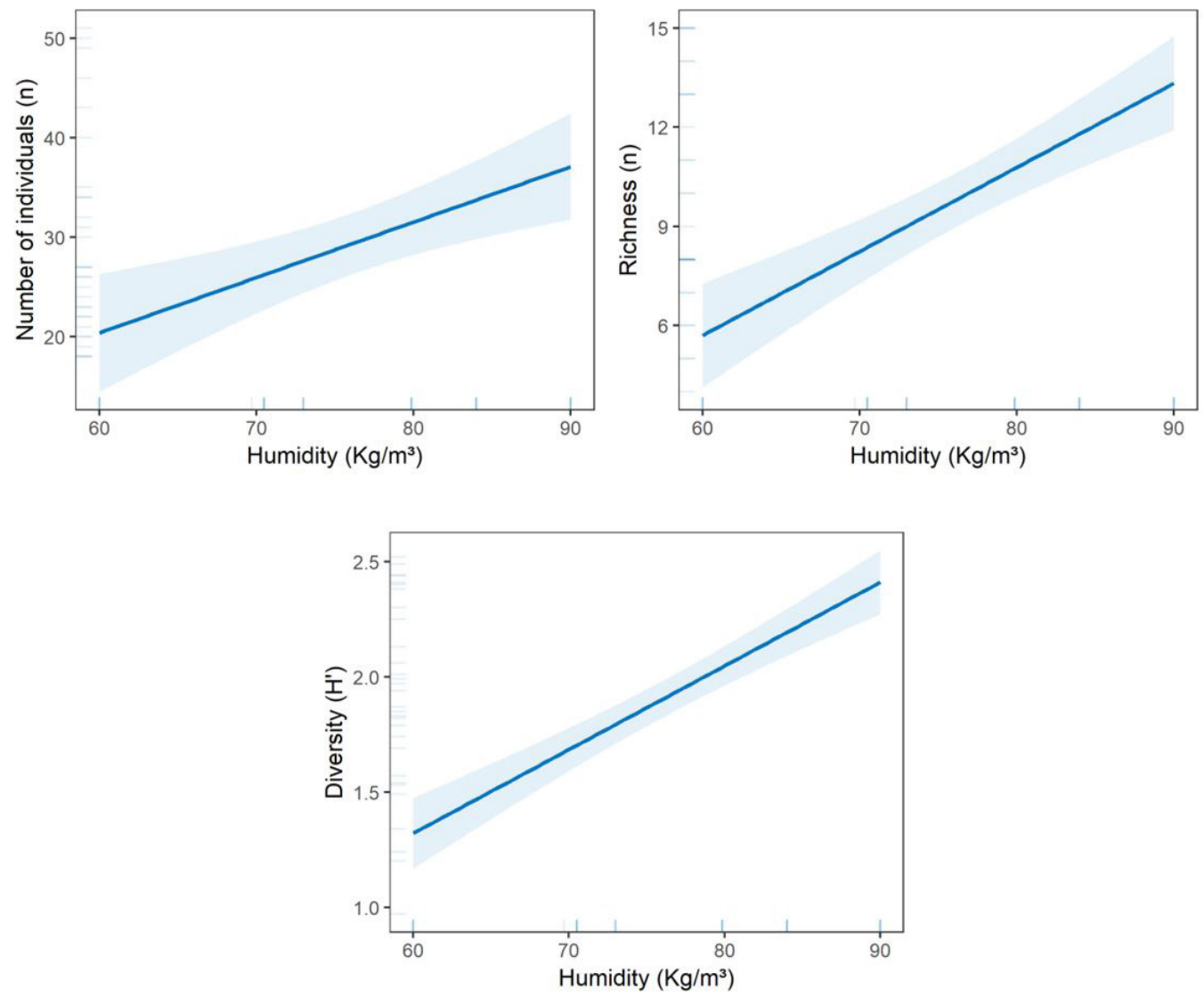

Figure 4. Multiple regression of humidify values related to number of individuals, richness and Shannon's diversity. Only significant predictors $(\mathrm{p}<0.05)$ were considered for plotting. 


\section{DISCUSSION}

The data support that there is difference in the structure and composition of edaphic macrofauna among phytophysiognomies plants, resulting from the distinction between the analyzed environments that formed a gradient of complexity (SF $>\mathrm{GE}>\mathrm{NE}$ ). Tropical secondary forests are environments with a richness of species and micro-habitats that can be used by a variety of organisms. When these forests are replaced by monocultures, there is a simplification of the environment that reflects throughout the biota, including in the edaphic fauna community (Baretta et al., 2011; Frevolente et al., 2012; Garlet et al., 2013; Chang et al., 2017; Laird-Hopkins et al., 2017; Kooch et al., 2018). This is what happened to the non-girdled eucalyptus areas with lower values for abundance, richness and diversity when compared to the other areas analyzed.

On the other hand, the proximity of the values of the community descriptors of edaphic macrofauna between secondary forest and girdled eucalyptus areas indicates that the management provided greater complexity to the managed environment. The secondary forest functioned as a reference indicating that the management of eucalyptus by girdling is causing positive effects on the edaphic macrofauna. This is due to the heterogeneity in the supply of resources, because the greater the diversity of the plant community, the greater the heterogeneity of the litterfall, which will present more niches to be colonized, resulting in a greater diversity of soil fauna communities (Handa et al., 2014; Rodrigues et al., 2017; Camara et al., 2018; Wu \& Wang, 2019; Nunes et al., 2019), suggesting that in the short term there are beneficial effects of management by girdling on the natural regeneration of native vegetation.

The results obtained corroborate the hypothesis proposed by this study, since the areas that underwent management by girdling presented higher values for the community descriptors when compared to the non-girdled eucalyptus areas. This was due to changes in the environment resulting from the inhibition of C. citriodora eucalyptus action. The litterfall produced by monocultures of this type of eucalyptus is homogeneous and of poor quality due to the high concentration of lignin, a substance resistant to decomposition, which reduces the mineralization of nutrients that will be used by plants (Tacca et al., 2017).
In addition, the C. citriodora litterfall is considered as unpalatable for some species of the soil macrofauna, besides being a chemical barrier against the natural regeneration of native species (Frainer \& Duarte, 2009; Diniz et al., 2011). Thus, the C. citriodora species is indicated as inhibitor of the natural regeneration of native forests since the decomposition and the cycling of nutrients are not favored in environments with the presence of this species (Valpassos et al., 2007; Evaristo et al., 2011).

The results of the present study resemble those found by Camara et al. (2012), who also studied the edaphic macrofauna comparing areas of secondary forest with areas of eucalyptus management (young and mature). The secondary forest area presented a more complex community (greater richness and abundance) and the arthropod community was more diverse when the environment was in a more advanced stage in regeneration, that is, in areas managed for longer time.

Suguituru et al. (2011) in a study in the Atlantic Forest, evaluating the ant community in secondary forest and eucalyptus plantations of several ages and management, found that greater richness in the secondary forest and in abandoned eucalyptus plantations. Other studies comparing the composition of the soil macrofauna among areas of eucalyptus with others has demonstrated that the presence of eucalyptus can inhibit the presence of several macroinvertebrates (Soares et al., 2010; Camara et al., 2012; Bartz et al., 2014; Tacca et al., 2017; Winck et al., 2017).

The nMDS generated in this study obeyed the standard raised by the other analyzes, evidencing the significant difference among the three phytophysiognomies. It is worth mentioning that the dissimilarity between secondary forest and girdled eucalyptus was lower than (SF $x \mathrm{NE}$ ) and (GE $x \mathrm{NE}$ ), which confirms that both girdled eucalyptus areas are changing toward secondary forest, through natural regeneration after handling by girdling.

The association pattern of edaphic macrofauna differed among phytophysiognomies (Amazonas et al., 2018; Camara et al., 2018). However, in all the analyzed areas, the individuals of the Formicidae family were the ones that contributed the most to the composition of the groups formed, with a difference in the contribution percentage for each phytophysiognomy. This group acts in the cycling of nutrients, in the control of the 
population of other invertebrates, since it is among the biggest predators of other insects, in addition to acting as seed disperser (King, 2016).

In the non-girdled eucalyptus areas, the Formicidae family presented greater participation in the similarity among the areas, due to the resistance of some groups of leaf-cutting ants (Atta and Acromyrmex) to the eucalyptus planting. The secondary forest and girdled eucalyptus areas showed lower participation of this group of ants and also a greater number of different taxa found, resulting from the greater stability and greater complexity of these environments.

This study also demonstrate that the edaphic macrofauna responded to the management by girdling through the stimulation of taxonomic groups in all guilds. This is probably due to the specificities that the soil macrofauna possesses, especially regarding the environmental conditions presented in the areas of unmanaged eucalyptus plantations, which has caused the inhibition of some taxonomic groups (Evaristo et al., 2011; Maestri et al., 2013).

Thus, the high diversity of guilds is advantageous, since the group can function more efficiently under a variety of environmental circumstances. The more diverse systems are more resilient to disturbances, if one group is compromised, the other (s) that prevails can compensate for it/them, doing the same ecological role in that ecosystem (Correia et al., 2018; Ferreira et al., 2018; Quadros \& Zimmer, 2018). On the other hand, the most diverse ecosystems may be less efficient since a greater proportion of available energy is used to combat the competitive interactions between redundant organisms, a situation that can be accentuated by the functional similarity of the groups, that is, a potential competition of niche (Salomão et al., 2019).

The most stimulated guilds were Phytophagous and Ecosystem Engineers (Melo et al., 2009). It stands out the guild of the Ecosystem Engineers, composed by earthworms and termites. These organisms produce large excrements that are part of the macroaggregate structure and participate in the formation of stable structures that regulate porosity, density and other soil properties (King, 2016; Coyle et al., 2017). Thus, directly or indirectly, they modulate the availability of resources to other species, creating and/or maintaining habitats that can be exploited by certain species (Baretta et al.,
2011), which may promote increased richness and abundance of the edaphic macrofauna as a whole.

The Isoptera were prominent in the areas of girdled eucalyptus as one of the taxonomic groups that contributed most to the similarity within this phytophysiognomy and did not have importance for the other two phytophysiognomies. This is because the girdled eucalyptus areas have abundant resource for this group, the eucalyptus trees killed by the girdling management. The Isoptera are typical ecosystem engineers, these organisms are specialized in a food based on lignocellulose materials and can fix the atmospheric nitrogen from the anaerobic bacteria that inhabit their digestive tract (Baretta et al., 2011; King, 2016). This symbiosis, together with the overabundance of Isoptera, gives this taxon a key role in the decomposition and stabilization of the carbon-nitrogen balance (Melo et al., 2009; King, 2016). Thus, dead organic matter with high $\mathrm{C} / \mathrm{N}$ ratio, an overabundant resource, as in the case of girdled eucalyptus, becomes a "protected" food resource, due to its difficult utilization and assimilation related to the unbalance of the $\mathrm{C} / \mathrm{N}$, niche, which throughout evolutionary time was essentially monopolized by termites (Higashi et al., 1992).

\section{CONCLUSION}

The hypothesis proposed by this study was accepted, considering that the areas that underwent annealing present greater abundance, richness and diversity of the edaphic macrofauna when compared to the unmanaged eucalyptus areas. This difference may be related to structural differences in areas where individuals of C. citriodora species were not girdled. This study also allowed us to observe that the edaphic macrofauna responds to management by girdling, through the stimulation of taxonomic groups in the various guilds and can be pointed as a good indicator of recovery of disturbed areas.

\section{ACKNOWLEDGEMENTS}

We thank to Carolina Rabelo de Almeida for her help in identifying biological material; Laboratório de Ciências Ambientais/UENF and Biological Reserve União for the logistical support. 


\section{SUBMISSION STATUS}

Received: 11 apr., 2019

Accepted: 24 sept., 2019

\section{CORRESPONDENCE TO}

\section{Paola Maia Lo Sardo}

Universidade Estadual do Norte Fluminense

- UENF, Av. Alberto Lamego, 2000, Parque

Califórnia, CEP 28015-556, Campos dos

Goytacazes, RJ, Brasil

e-mail:pmaialosardo@gmail.com

\section{FINANCIAL SUPPORT}

Coordenação de Aperfeiçoamento de Pessoal de Nível Superior (Grant/Award Number: 'Finance Code 001') and Fundação Carlos Chagas Filho de Amparo à Pesquisa do Estado do Rio de Janeiro (Grant/Award Number: E_01/2018).

\section{REFERENCES}

Amazonas NT, Viani RAG, Rego MGA, Camargo FF, Fujihara RT, Valsechi OA. Soil macrofauna density and diversity across a chronosequence of tropical forest restoration in Southeastern Brazil. Brazilian Journal of Biology = Revista Brasileira de Biologia 2018; 78(3): 449-456. http://dx.doi.org/10.1590/1519-6984.169014. PMid:29185609.

Baretta D, Santos JCP, Segat JC, Geremia EV, Oliveira LCL Fo, Alves MV. Fauna edáfica e qualidade do solo. In: Klauberg O Fo, Mafra AL, editors. Tópicos em ciência do solo. Vol. 7. Viçosa: Sociedade Brasileira de Ciência do Solo; 2011. p. 119-170.

Bartz MLC, Brown GG, Orso R, Mafra AL, Baretta D. The influence of land use systems on soil and surface litter fauna in the western region of Santa Catarina. Ciência Agronômica 2014; 45(5): 880-887. http://dx.doi. org/10.1590/S1806-66902014000500003.

Borges CHA, Souto JS, Silva ACF, Alencar LS, Limeira MQR, Santos AC et al. Edaphic arthropods in fragment of riparian forest in the semi-arid of Paraíba. The Journal of Agricultural Science 2019; 11(2): 236-243. http://dx.doi. org/10.5539/jas.v11n2p236.

Camara R, Correia MEF, Villela DM. Effects of eucalyptus plantations on soil arthropod communities in a brazilian atlantic forest conservation unit. Bioscience Journal 2012; 28(3): 445-455.
Camara R, Santos GL, Pereira MG, Silva CF, Silva VFV, Silva RM. Effects of natural atlantic forest regeneration on soil fauna, Brazil. Floresta e Ambiente 2018; 25(1): 1-10.

Castro A, Wise DH. Influence of fine woody debris on spider diversity and community structure in forest leaf litter. Biodiversity and Conservation 2009; 18(14): 37053731. http://dx.doi.org/10.1007/s10531-009-9674-7.

Chang L, Wang B, Liu X, Callaham MA Jr, Feng GE. Recovery of Collembola in Pinus tabulaeformis Plantations. Pedosphere 2017; 27(1): 129-137. http://dx.doi.org/10.1016/ S1002-0160(15)60099-6.

Correia MEF, Camara R, Ferreira CR, Resende AS, Anjos LHC, Pereira MG. Soil fauna changes across Atlantic Forest succession. Comunicata Scientiae 2018; 9(2): 162-174. http://dx.doi.org/10.14295/cs.v9i2.2388.

Coyle DR, Nagendra UJ, Taylor MK, Campbell JH, Cunard CE, Joslin AH et al. MA. Soil fauna responses to natural disturbances, invasive species, and global climate change: current state of the science and a call to action. Soil Biology \& Biochemistry 2017; 110: 116-133. http:// dx.doi.org/10.1016/j.soilbio.2017.03.008.

Crotty FV, Blackshaw RP, Adl SM, Inger R, Murray PJ. Divergence of feeding channels within the soil food web determined by ecosystem type. Ecology and Evolution 2014; 4(1): 1-13. http://dx.doi.org/10.1002/ece3.905. PMid:24455156.

Cunha F No, Correira MEF, Pereira GHA, Almeida H, Pereira MG, Leles PSS. Fauna edáfica como indicador da qualidade do solo em povoamentos florestais, pastagem e floresta secundária. Revista Brasileira de Ciência do Solo 2012; 36(5): 1407-1417. http://dx.doi.org/10.1590/ S0100-06832012000500004.

Diniz AR, Pereira MG, Loss A. Aporte de material decíduo nutrientes para o solo em plantio de eucalipto e floresta secundária. Pesquisa Florestal Brasileira 2011;31(65): 1926. http://dx.doi.org/10.4336/2011.pfb.31.65.19.

Evaristo VT, Braga JMA, Nascimento MT. Atlantic Forest regeneration in abandoned plantations of eucalypt (Corymbia citriodora (Hook.) K. D. Hill and L. A. S. Johnson) in Rio de Janeiro, Brazil. Interciencia 2011; 36(6): 431-436.

Ferreira ML, Souza LC, Conti DM, Quaresma CC, Tavares $\mathrm{AR}$, Silva KG et al. Soil biodiversity in urban forests as a consequence of litterfall management: implications for São Paulo’s ecosystem services. Sustainability 2018; 684(10): 1-13. PMid:30607262.

Frainer A, Duarte MM. Soil invertebrates in southern Brazilian Araucaria forest - grassland mosaic: differences between disturbed and undisturbed areas. Iheringia: Série Zoologia 2009; 99(3): 307-312. http://dx.doi.org/10.1590/ S0073-47212009000300013.

Frevolente M, Brigante J, Fogo JC, Mendonça AH. Análise da relação entre a complexidade vegetacional e as 
comunidades da macrofauna do solo. Revista de Biologia e Ciências da Terra 2012; 12(1): 57-69.

Garlet J, Costa EC, Boscardin J. Caracterização da fauna edáfica em plantios de Eucalyptus spp. Ciência Florestal 2013; 23(3): 337-344. http://dx.doi.org/10.5902/1980509810545.

Gerisch M, Agostinelli V, Henle K, Dziock F. More species, but all do the same: contrasting effects of flood disturbance on ground beetle functional and species diversity. Oikos 2012; 121(4): 508-515. http://dx.doi.org/10.1111/j.16000706.2011.19749.x.

Handa IT, Aerts R, Berendse F, Berg MP, Bruder A, Butenschoen $\mathrm{O}$ et al. Consequences of biodiversity loss litter decomposition across biomes. Nature 2014; 509(7499): 218-221. http://dx.doi.org/10.1038/nature13247. PMid:24805346.

Higashi M, Abe T, Burns TP. Carbon-nitrogen balance and térmite ecology. Proceedings of the Royal Society of London. Series B, Biological Sciences 1992; 249(1326): 303-308. http://dx.doi.org/10.1098/rspb.1992.0119.

Instituto Chico Mendes de Conservação da Biodiversidade - ICMBio. Plano de recuperação ambiental dos eucaliptais da Reserva Biológica União. Rio das Ostras: Reserva Biológica União, Associação Mico-leão Dourado, Critical Ecosystem Partnership Fund; 2007.

Instituto Chico Mendes de Conservação da Biodiversidade - ICMBio. Plano de manejo da Reserva Biológica União: encarte 2 análise da região da Unidade de Conservação. Rio das Ostras: Reserva Biológica União, Associação Mico-leão Dourado, Critical Ecosystem Partnership Fund; 2008.

King JR. Where do eusocial insects fit into soil food webs? Soil Biology \& Biochemistry 2016; 102: 55-62. http://dx.doi. org/10.1016/j.soilbio.2016.07.019.

Kooch Y, Tavakoli M, Akbarinia M. Tree species could have substantial consequences on topsoil fauna: a feedback of land degradation/restoration. European Journal of Forest Research 2018; 137(6): 793-805. http://dx.doi.org/10.1007/ s10342-018-1140-1.

Laird-Hopkins BC, Brechet LM, Trujillo BC, Sayer EJ. Tree functional diversity affects litter decomposition and arthropod community composition in a tropical forest. Biotropica 2017; 49(6): 903-911. http://dx.doi. org/10.1111/btp.12477.

Maestri R, Leite MAS, Schmitt LZ, Restello RM. Effect of native forests and forest of eucalyptus on arthropods richness in the litter. Perspectiva 2013; 37: 31-40.

Majeed MZ, Raza ABM, Afzal M, Salah-ud-Din H, Sarwar I, Yahya M et al. Differential impact of different land-use types on the population density and community assemblages of edaphic macroinvertebrates in district Sargodha, Punjab, Pakistan. Pakistan Journal of Zoology 2018; 50(3): 911-919. http://dx.doi.org/10.17582/journal. pjz/2018.50.3.911.919.
Marques DM, Silva AB, Silva LM, Moreira EA, Pinto GS. Macrofauna edáfica em diferentes coberturas vegetais. Bioscience Journal 2014; 30(5): 1588-1597.

Marx MT, Yan X, Wang X, Song L, Wang K, Zhang $B$ et al. Soil fauna abundance, feeding and decomposition in different reclaimed and natural sites in the Sanjiang Plain Wetland, Northeast China. Wetlands 2016; 36(3): 445-455. http://dx.doi.org/10.1007/s13157-016-0753-8.

Melo FV, Brown GG, Constantino R, Louzada JNC, Luizão FJ, Morais JW et al. A importância da meso e macrofauna do solo na fertilidade e como biondicadores. Boletim Informativo da Sociedade Brasileira de Ciência do Solo 2009; 34(1): 39-43.

Nakamura A, Catterall CP, House APN, Kitching RL, Burwell CJ. The use of ants and other soil and litter arthropods as bio-indicators of the impacts of rainforest clearing and subsequent land use. Journal of Insect Conservation 2011; 11(2): 177-186. http://dx.doi.org/10.1007/s10841006-9034-9.

Nunes LAPL, Araújo ASF, Pessoa MMC, Sousa RS, Silva JDC, Matos-Filho CHA. Edaphic fauna in a vegetation gradient in the Sete Cidades National Park. Brazilian Journal of Biology = Revista Brasileira de Biologia 2019; 79(1): 45-51. http://dx.doi.org/10.1590/1519-6984.174135. PMid:29641637.

Ober HK, Degroote LW. Effects of litter removal on arthropod communities in pine plantations. Biodiversity and Conservation 2011; 20(6): 1273-1286. http://dx.doi. org/10.1007/s10531-011-0027-y.

Quadros AF, Zimmer M. Aboveground macrodetritivores and belowground soil processes: insights on species redundancy. Applied Soil Ecology 2018; 124: 83-87. http:// dx.doi.org/10.1016/j.apsoil.2017.11.008.

Rodrigues PES, Costa-Schmidt LE, Ott R, Rodrigues ENL. Influence of forest structure upon the diversity and composition of edaphic diplopods. Journal of Insect Conservation 2017; 21(2): 297-306. http://dx.doi. org/10.1007/s10841-017-9976-0.

Salomão RP, Brito LC, Iannuzzi L, Lira AFA, Albuquerque CMR. Effects of environmental parameters on beetle assemblage in a fragmented tropical rainforest of South America. Journal of Insect Conservation 2019; 23(1): 111-121. http://dx.doi.org/10.1007/s10841-018-00120-y.

Sayer EJ, Sutcliffe LME, Ross RIC, Tanner EVJ. Arthropod abundance and diversity in a lowland tropical forest floor in Panama: the role of habitat space vs. nutrient concentrations. Biotropica 2010; 42(2): 194-200. http:// dx.doi.org/10.1111/j.1744-7429.2009.00576.x.

Silva CF, Martins MA, Silva EMR, Pereira MG, Correia MEF. Influência do sistema de plantio sobre atributos dendrométricos e fauna edáfica, em área degradada pela extração de argila. Revista Brasileira de Ciência do Solo 2013; 37(6): 1742-1751. http://dx.doi.org/10.1590/ S0100-06832013000600030. 
Silva R, Nascimento LF, Santos VC, Carregaro JB. Comparação da artropodofauna em monocultura de eucaliptos e cerrado da Flona no Distrito Federal. Ensaios e Ciência: Ciências Biológicas, Agrárias e da Saúde 2012; 16(2): 105-114.

Silva RA, Siqueira GM, Costa MKL, Guedes O Fo, Silva EFF. Spatial variability of soil fauna under different land use and managements. Revista Brasileira de Ciência do Solo 2018; 42(0): 1-18. http://dx.doi.org/10.1590/18069 $657 \mathrm{rbcs} 20170121$.

Soares SA, Antonialli-Junior WF, Lima-Junior SE. Diversidade de formigas epigéicas (Hymenoptera, Formicidae) em dois ambientes no Centro-Oeste do Brasil. Revista Brasileira de Entomologia 2010; 54(1): 76-81. http://dx.doi.org/10.1590/ S0085-56262010000100009.

Suguituru SS, Silva RR, Souza DR, Munhae CB, Morini MSC. Ant community richness and composition across a gradient from Eucalyptus plantations to secondary Atlantic Forest. Biota Neotropica 2011; 11(1): 369-376. http://dx.doi.org/10.1590/S1676-06032011000100034.

Swift MJ, Bignell D, Moreira FMS, Huising J. O inventário da biodiversidade biológica do solo: conceitos e orientações gerais. In: Moreira FMS, Huising EJ, Bignell DE, editors. Manual de biologia dos solos tropicais: amostragem e caracterização da biodiversidade. Lavras: Editora UFLA; 2010 .

Tacca D, Klein C, Preuss JF. Artropodofauna do solo em um bosque de eucalipto e um remanescente de mata nativa no sul do Brasil. Revista Thema 2017; 14(2): 249-261. http://dx.doi.org/10.15536/thema.14.2017.249-261.456.

Valpassos MAR, Maltoni KL, Cassiolato AMR, Nahas E. Recovery of soil microbiological properties in a degraded area planted with Corymbia citriodora and Leucaena leucocephala. Scientia Agrícola 2007; 64(1): 68-72. http:// dx.doi.org/10.1590/S0103-90162007000100010.

Vasconcellos RLF, Segat JC, Bonfim JA, Baretta D, Cardoso EJBN. Soil macrofauna as an indicator of soil quality in an undisturbed riparian forest and recovering sites of different ages. European Journal of Soil Biology 2013; 58: 105-112. http://dx.doi.org/10.1016/j.ejsobi.2013.07.001.

Wardle DA, Parkinson D. Analyses of co-ocurrence in a fungal community. Mycological Research 1991; 95(4): $504-$ 505. http://dx.doi.org/10.1016/S0953-7562(09)80855-1.

Winck BR, Sá ELS, Rigotti VM, Chauvat M. Relationship between land-use types and functional diversity of epigeic Collembola in Southern Brazil. Applied Soil Ecology 2017; 109: 49-59. http://dx.doi.org/10.1016/j.apsoil.2016.09.021.

Wu P, Wang C. Differences in spatiotemporal dynamics between soil macrofauna and mesofauna communities in forest ecosystems: the significance for soil fauna diversity monitoring. Geoderma 2019; 337: 266-272. http://dx.doi. org/10.1016/j.geoderma.2018.09.031.

Yin R, Eisenhauer N, Auge H, Purahong W, Schmidt A, Schädler M. Additive effects of experimental climate change and land use on faunal contribution to litter decomposition. Soil Biology \& Biochemistry 2019; 131: 141-148. http://dx.doi.org/10.1016/j.soilbio.2019.01.009.

Zardo DC, Carneiro AP, Lima LG, Santos-Filho M. Comunidade de artrópodes associada à serrapilheira de cerrado e de mata de galeria, na estação ecológica Serra das Araras - Mato Grosso do Sul, Brasil. Revista Uniara 2010; 13(2): 105-113. http://dx.doi.org/10.25061/25272675/ReBraM/2010.v13i2.143. 